\title{
O fascismo travestido de nacionalismo no Brasil: consequências sociais e jurídicas
}

\author{
Fascism dressed up as nationalism in Brazil: social and legal consequences
}

\author{
Cesar Bessa* \\ Francielly Podanoschi de Castro**
}

\begin{abstract}
Resumo
Esse artigo abre um debate acerca da origem do Estado, como se dá sua gênese, distinguindo-o de nação, no aspecto jurídico e filosófico para, em seguida, adentrar no conceito de nacionalismo e o ressurgimento desse conceito no mundo. Logo após essa análise, abordou-se o panorama brasileiro contemporâneo do nacionalismo, demonstrando a sua verdadeira vertente e a mais temerária: o fascismo. Dessa forma, convida-se o leitor ao exercício da exegese acerca do tema, ao final demonstrando os efeitos reais de implicações legais e sociais acerca desse fenômeno, bem como, se é possível uma solução ao que fora acometido ao cenário legal e político brasileiro.
\end{abstract}

Palavras-chave: Democracia. Direito. Fascismo. Nacionalismo. Sociedade.

\begin{abstract}
This article opens a debate about the origin of the State, as its genesis, distinguishing it from nation, in the juridical and philosophical aspect, and then entering the concept of nationalism and the resurgence of this concept in the world. Soon after this analysis, we will approach the contemporary Brazilian panorama of nationalism, demonstrating its true and the most reckless aspect: fascism. Thus, we invite the reader to exercise the exegesis on the subject, in the end we will demonstrate the real effects of legal and social implications on this phenomenon, as well as, if it is possible a solution to what will happen in the national political scenario.
\end{abstract}

Keywords: Democracy. Fascism. Law. Nationalism. Society.

\footnotetext{
* Professor de Direito do Trabalho e Introdução ao Estudo do Direito da Universidade Estadual de Londrina, Doutor em Direito do Trabalho pela UFPR.

** Advogada, Mestranda em Direito Negocial na Universidade Estadual de Londrina, Doutoranda em Ciências Jurídicas na UMSA-Argentina.
} 


\section{Introdução}

Ao se debater acerca de movimentos nacionalistas, vinculou-se imediatamente a uma anomalia na história recente que causou e causa horror: o nazismo e o fascismo.

É imaginando-se como seria possível que toda uma nação alemã tivesse ratificado os atos iniciais do governo "nacional socialista dos trabalhadores alemães", que incita a necessidade de pesquisa para a confecção deste artigo.

Para tanto, buscou-se conceituar Estado, nação e território para analisar como certo grupo de pessoas pode identificar ao ponto de se denominarem cidadãos de determinada nação e quais os efeitos do pensamento nacionalista sobre os indivíduos que compõe e que não compõe esse mesmo grupo.

Bem como, abordar-se-á sobre os movimentos nacionalistas que existiram no passado recente da humanidade, seu ressurgimento, mesmo após o que fora experimentado na II Guerra Mundial, principalmente em breve apreciação histórica da política brasileira.

Ao final do debate, far-se-á uma análise psicanalítica para justificar o ressurgimento do nacionalismo no Brasil, demonstrando a repercussão no âmbito político e legislativo da entronização do movimento nacionalista no governo atual.

\section{Conceito jurídico de Estado}

É primaz analisar conceitos basilares à construção jurídica e social de Estado, nação e território para, em sequência, realizar a exegese sobre o fenômeno social e político denominado nacionalismo.

Aristóteles em "Política" já escrevia sobre a ficção "Estado", contudo, com a denominação de pólis, ou seja, cidade, começando pela organização política de Atenas e Esparta, os órgãos de governo dessas cidades, chegando a uma classificação de todas as formas de governos até então existentes, dispondo:

Como sabemos, toda cidade é uma sociedade, a esperança de um bem, seu princípio, assim como de toda associação, pois todas as ações dos homens têm por fim aquilo que consideram um bem. Todas as sociedades, portanto, têm como meta alguma vantagem, e aquela que é a principal e contém em si todas as outras se propõe a maior vantagem possível (ARISTÓTELES, 2004, p. 10). 
Ou seja, para Aristóteles o vínculo existente nos indivíduos que compõe um Estado advém de interesses existentes entre esses, visando o bem comum dessa sociedade.

Hannah Arendt (1983, p. 227), citando Aristóteles, entende que a comunidade política configurada no Estado seria composta por desiguais que precisariam se igualar, o que é oposto a qualquer igualdade advinda naturalmente, ou seja, consenso de ideias. Para a autora judia, o cerne do Estado é trabalhar essas divergências, para que se harmonizem, colaborem, não chegando à violência, ou caos social.

Sobre a possiblidade de harmonia social, observa-se a Teoria do Agir Comunicativo trazida por Jürgen Habermas, onde se prioriza o diálogo para a promoção social, bem como, o surgimento das normas deve se dar por intermédio desse diálogo racional, levando a autonomia para a liberdade comunicativa:

[...] procura obter um conteúdo normativo da própria prática de argumentação, da qual nos sentimos dependentes sempre que nos encontramos numa situação insegura - não apenas como filósofos ou cientistas, mas também quando, em nossa prática comunicativa cotidiana, a quebra de rotinas nos obriga a parar um momento e refletir, a fim de nos certificarmos reflexivamente acerca de expectativas justificada (HABERMAS, 2007, p. 96).

E ainda:

[...] compete aos destinatários decidir se eles, enquanto autores, vão empregar sua vontade livre, se vão passar por uma mudança de perspectivas que os faça sair do círculo dos próprios interesses e passar ao entendimento sobre normas capazes de receber o assentimento geral, se vão ou não fazer um uso público de sua liberdade comunicativa, [ou seja], as instituições jurídicas da liberdade decompõem-se quando inexistem iniciativas de uma população acostumada à liberdade. Sua espontaneidade não pode ser forçada através do direito; ele se regenera através das tradições libertárias e se mantém nas condições associacionais de uma cultura política liberal (HABERMAS, 1997, I, p. 167-168).

Poderia se afirmar, portanto, que a concepção de Estado, para Hanna Arendt, seria uma junção de desiguais que buscam uma equidade e se coaduna com a teoria habermasiana, que, buscaria um equilíbrio social, de agir diferentes que, por meio do diálogo racional entre os partícipes dessa composição social poder-se-ia chegar à moral dentro deste Estado.

Prosseguindo traz-se o entendimento de Hans Kelsen sobre Estado, que seria uma entidade real, sociológica ou jurídica, criada pela ordem jurídica nacional. Para Kelsen "aquilo que se concebe como forma do Estado é apenas um caso especial da forma do Direito em 
geral" (KELSEN, 2006, p. 200). Propondo ainda que Estado necessitaria de outras características para assim se configurar: “Como organização política, o Estado é uma ordem jurídica. Mas nem toda ordem jurídica é um Estado" (KELSEN, 2006, p. 200)

Dessa forma, segundo Kelsen, a relação entre o Direito e o Estado se compara à existência entre o Direito e o indivíduo.

Tem-se ainda que, para o reconhecimento de um Estado deve-se ter a presença unificada de um povo, território uníssono e soberania diante dos demais Estados como assevera José Gomes Canotilho, quando trata dos elementos constitutivos:

[...] o conceito de Estado é assumido como uma forma histórica (a última para os modernos, porventura a penúltima para os pós-modernos) de um ordenamento jurídico geral cujas características ou elementos constitutivos eram os seguintes: (1) - territorialidade, isto é, a existência de um território concebido como "espaço da soberania estadual; (2) - população, ou seja, a existência de um "povo" ou comunidade historicamente definida (CANOTILHO, 1993, p. 14).

Portanto, tem-se como primeiro que constitui o Estado, sendo o território ao qual pertence:

O segundo elemento essencial à existência do Estado é o território, a base física, a porção do globo por ele ocupada, que serve de limite à sua jurisdição e lhe fornece recursos materiais. O território é o país propriamente dito, e, portanto país não se confunde com povo ou nação, e não é sinônimo de Estado, do qual constitui apenas um elemento (CANOTILHO, 1999, p. 36).

Tem-se ainda o segundo elemento o povo, a nação, porém, há uma distinção nesses dois conceitos, conforme entendimento a seguir exposto:

\footnotetext{
Nação é um grupo de indivíduos que se sentem unidos pela origem comum, pelos interesses comuns e, principalmente, por ideais e aspirações comuns. Povo é uma entidade jurídica; nação é uma entidade moral no sentido rigoroso da palavra. Nação é muita coisa mais do que povo, é uma comunidade de consciências, unidas por um sentimento complexo, indefinível e poderosíssimo: o patriotismo (AZAMBUJA, 1999, p. 19).
}

O terceiro elemento da formação de um Estado é a soberania, trata-se de um dos mais obscuros e controvertidos conceitos.

Para André Ramos Tavares, a soberania detém dois elementos fundamentais: "a independência na ordem internacional e a supremacia na ordem interna" (TAVARES, 2012, p. 1068). 
Ainda o mencionado autor, acerca do conceito controvertido de soberania, cita Machado Paupério "A vontade do Estado soberano não depende de nenhuma outra vontade. É a vontade suprema, garantida, se necessário, pela força coatora de que dispõe, pela própria natureza, a entidade estatal" (apud, TAVARES, 2012, p. 1070).

O pacto social é um fator determinante de uma nova concepção desse instituto, onde a soberania se concentra na autoridade do poder representante, na hierarquia dos órgãos integrantes da administração pública. Pode-se dizer, nesta análise, que a soberania pertenceria ao povo, o povo deve se submeter à soberania do Estado.

Portanto, conclui-se de que a denominação "Estado" se caracteriza por ser uma sociedade natural, pois sua gênese decorre do fato do homem viver em sociedade, em determinado território e essa comunidade almeja realizar o bem geral que lhes é próprio. Logo, as leis, a constituição que é o regramento geral de uma nação, unifica esse intuito comum de um povo que pretende se organizar socialmente.

\section{O Estado deve existir para o homem e não o homem para o Estado}

Essa frase é de José Pedro Galvão de Sousa ${ }^{1}$, que interpreta o Estado como ente que não pode criar seu próprio direito e impor a sociedade uma ordem jurídica, mas sim, o direito deve advir dessa regulação natural, ou seja, preexistiriam.

Sobre preexistência dos direitos, Dworkin, ao criticar o positivismo, não admite a ideia de que os direitos jurídicos possam preexistir a qualquer forma de legislação e Estado, senão, essas poderiam ser aplicadas na maneira "tudo ou nada" (DWORKIN, 2010, p. 39).

Muitos direitos são conquistados arduamente pelos cidadãos ao longo dos anos, como o direito ao voto, os direitos humanos predispostos na Constituição Federal por intermédio dos direitos e garantias fundamentais, dentre os quais direitos sociais tem sido extremamente atacados pelas denominadas reformas trabalhistas e previdenciárias.

\footnotetext{
${ }^{1}$ SOUSA, José Pedro Galvão de. Direito natural, direito positivo e estado de direito. Revista dos Tribunais, São Paulo, 1977, p. 45.
} 
Ou seja, somente existirá o Estado de Direito havendo respeito ao Direito Natural, garantindo uma boa constituinte e ainda, o respeito ao contexto histórico do povo, nação, a qual ver-se-á uma distinção.

\section{Nação e sua distinção de Estado}

Atualmente a palavra nação se traduz por ser um conjunto de indivíduos que possuem interesses comuns sociais e econômicos sob um certo território, e ainda:

[...] que reconhecem a existência de um passado comum, ainda que divirjam sobre aspectos desse passado; que têm uma visão de futuro em comum; e que acreditam que esse futuro será melhor se se mantiverem unidos do que se separarem, ainda que alguns aspirem modificar a organização social da nação e seu sistema político, o Estado (GUIMARÃES, 2008, p. 145).

Para Friedrich Carl von Savigny², que tinha aversão à codificação e legislação o conceito de nação se define como cerne da consciência jurídica comum ou popular e não a legislação em si:

[...] coletividade política que ao ser construída absorve elementos históricos e culturais que a identificam e a diferenciam em relação às demais. Savigny utiliza tal ideia, por exemplo, quando se contrapõe à fúria dos codificadores, ao levantar a voz em favor do respeito ao que seria o "espírito da Nação. Este último, segundo ele, se encontraria em diversos aspectos da vida cultural, refletindo-se no percurso histórico das instituições do direito civil (DAL RI JUNIOR. 2011, p. 71-72).

Crítico de Savigny, Rudolf von Ihering preconiza que "a teoria de Savigny aplicar-seia somente à época pré-histórica, “[...] me fosse permitido formular hipóteses, oporei a minha teoria à teoria de Savigny, que caracterizou essas priscas eras como cenários de formação calma e pacífica de um direito formado pela consciência popular" (IHERING, p. 34). Ou seja, para Ihering, Savigny realizou uma análise ingênua acerca da desnecessidade de codificação das leis, pois, para ele, um Estado apenas surge e se compõe pelas leis.

Em outra análise, pode-se observar que o conceito de nação se contrapõe ao conceito de Estado, pois se relaciona à ideia de comunidade, conforme preconiza Baalbaki a nação estaria relacionada:

\footnotetext{
${ }^{2}$ SAVIGNY, Friederich Carl von. Traité de droit romain. Tome 1. Paris: Firmin Didot Frères, 1840.
} 
[...] à ideia de comunidade, cujas características assim se delineiam: existência independente da vontade; inexistência de objetivo (há somente um sentimento de preservação); ausência de vínculos jurídicos (existência só de sentimentos comuns) e inexistência de poder.

[...] o artifício de se empregar o termo Nação, que deflagra reações emocionais no povo, objetivava afastar do poder os monarcas, responsáveis diretos pelas guerras intermináveis e, por outro lado, possibilitar que a burguesia conquistasse o poder político" (BAALBAKI, 2005, p.1).

E já Estado, como debatido, tem mais conexão com a ideia de vínculo jurídico, objetivos comuns, ideais comuns em que a vontade individual se sobrepuja à coletividade.

O professor Samuel Pinheiro Guimarães dispõe uma exegese acerca da distinção entre Nação e Estado:

A ideia de que o Estado nasce com a nação não corresponde à realidade na maior parte dos casos, pois a nação seria de fato uma construção ideológica posterior, tendo muitas vezes a nação sido "construída" pelo Estado. A emergência natural das nações teria sido em realidade impossível em razão da ignorância das massas, da diversidade de etnias e de religiões, da ausência de tradições reais, efetivas, da tardia fixação das línguas, das difusas tradições orais e, portanto, a emergência de uma nação teria sido somente possível após o surgimento do Estado moderno (PINHEIRO, 2008, p. 148).

Após discorrer acerca dos conceitos de Estado, nação e território, pode se adentrar no tema nacionalismo, descobrir sua origem etimológica e o que propõe esse movimento social inicialmente. Após, se fez uma investigação dos motivos e de seu ressurgimento e qual a significância e repercussão no Estado brasileiro.

\section{Conceito de nacionalismo}

De acordo com Alexandre José Barbosa Lima Sobrinho tem-se a origem etimológica do nacionalismo:

[...] deriva de duas raízes, gen (nascer, fazer gerar) e natus, filho, como nos ensina José Arrais de Alencar no seu excelente Vocabulário latino, construído sobre alicerces etimológicos. Dessas origens vieram natio, nationis, nativus e, mais tarde, muito mais tarde, aliás, nacionalismo. No latim, natio definia um grupo de homens, vinculados a uma origem comum, já assinalada pela consciência de sua unidade e o desejo de uma vida solidária (SOBRINHO, 2019, p. s/n).

O conceito de nacionalismo pode também advir de uma raiz religiosa, em crer na superioridade advinda de uma divindade, assim afirma Guimarães: 
O preconceito de considerar a sua nação melhor do que as demais tem sua origem na ideia de que as divindades teriam escolhido um povo, uma certa nação, como eleita, isto é, a nação como um conjunto de indivíduos que adoravam uma certa divindade (GUIMARÃES, 2008, p. 146).

E mais:

De um ponto de vista coletivo, o sucesso material da sociedade americana significaria um sinal de aprovação divina, de que a sociedade americana seria eleita pelo Senhor e que, por essa razão, não só poderia como deveria assumir o papel de líder e de modelo para todas as sociedades e Estados (GUIMARÃES, 2008, p. 147).

Nessa esteira, se tem que o movimento nacionalista alemão surgiu da exaltação da superioridade divina deste povo. Hitler detinha aconselhamentos esotéricos que o fez crer que "a raça ariana", como assim intitulava, era pura e superior, e utilizou a suástica como símbolo maior do nazismo, mesmo símbolo do povos antigos dos quais pensou descender o povo alemão:

Ornamentava, por exemplo, objetos decorativos e utensílios domésticos da antiga Mesopotâmia - atual Iraque - datadas de 7.000 a.C. Foi usado também por bizantinos na Europa, Maias e Astecas na América Central e índios Navajos na América do Norte. Para todos esses povos, a suástica era uma representação de boa sorte. Não por acaso, a palavra vem do sânscrito svastika, que quer dizer "condutora do bem-estar (CORDEIRO, 2018, p. s/n).

Nessa perspectiva, Max Weber, mencionado por Marilena Chauí (1995, p. 273), dispõe que, um Estado se determinada por uma dominação social, que, portanto, se identificaria no conceito inicial do nacionalismo:

Assim, por exemplo, o Estado se apresenta como uma forma de dominação social e política sob vários tipos ideais (dominação carismática, dominação pessoal burocrática etc.), cabendo ao cientista verificar sob qual tipo encontra-se o caso particular investigado.

Sobre a exegese de que enaltecer uma nação acabaria por depreciar e, talvez até mesmo explorar outra para enriquecimento próprio, conclui Voltaire:

Ser bom patriota significa desejar que a própria cidade se enriqueça com o comércio e se torne poderosa por meio das armas. Mas é claro que um país não pode ganhar se o outro não perde, não se pode vencer sem aumentar os infelizes. É tal a condição humana que desejar a grandeza do próprio país é desejar o mal dos vizinhos (apud TAVARES, 2012, p. 517-518). 
Analisando ainda sob um prisma de tratamento igualitário entre as nações, o que adveio de uma conclusão intelectual, pensa-se também que, muito antes de Voltaire, ou de qualquer outro grande pensador humanista, tais preceitos já estavam descritos pelos gregos, como postulou Demócrito, veritólogo pré-socrático, devido suas diversas viagens a povos distintos na região do Oriente Médio e Ásia, acabou por ser conhecido pela seguinte frase: “A pátria do homem sábio e bom é o mundo inteiro" (DURANT, 1943, p. 276).

Ademais, em igual período na constituição do cristianismo fora propagado esse mesmo conceito de igualdade entre todos os povos, se vê o que o jurista e doutrinador Fábio Konder Comparato discorre acerca de Paulo de Tarso com relação ao nacionalismo:

\begin{abstract}
A partir da pregação de Paulo de Tarso, na verdade o verdadeiro fundador da religião cristã enquanto corpo doutrinário, passou a ser superada a ideia de que o Deus único e transcendente havia privilegiado um povo entre todos, escolhendo-o como seu único e definitivo herdeiro. Algumas passagens dos Evangelhos demonstram o inconformismo de Jesus com essa concepção nacionalista da religião. São Paulo levou o universalismo evangélico às últimas consequências, ao afirmar que, diante da comum filiação divina, 'já não há nem judeu nem grego, nem escravo nem livre, nem homem nem mulher (COMPARATO, 2015, p. 17).
\end{abstract}

Em verdade, todo movimento nacionalista é xenofóbico, pois exalta a superioridade de uma nação em detrimento de outra. E, o surgimento desses movimentos ocorreu devido o intuito imperialista das nações europeias que originou a primeira guerra mundial.

Diante disso, verifica-se que, para justificar a superioridade de sua nação, povo, em detrimento dos demais, em muitos casos usou-se o "divino" como plausível. Contudo, este uso foi distorcido, pois, como citado acima, a pregação universal de muitas religiões é a igualdade, o respeito entre diferentes povos, não a prevalência e imposição de seus costumes, pois seriam melhores, aos demais.

O nacionalismo tem sua origem após a consolidação política dos Estados, a partir da Revolução Francesa, e de sua contradição, em que se há uma identidade soberana, não existindo mais a subordinação ao Rei, e sim, uma agremiação de um povo que se identifica num processo com a participação de todos.

E, lembrando, neste mesmo período havia um movimento cultural denominado romantismo, na literatura, nas artes em geral e que refletia, por sua vez, também em aspectos políticos. Isso se denota no amor incondicional à pátria, em que as pessoas se identificavam pertencentes, dando origem ao nacionalismo em gênese. 
Importante análise realiza o filósofo Jürgen Habermas ao debater acerca do nacionalismo, aborda como se dá sua propagação e sua utilização:

\footnotetext{
O nacionalismo pode ser tido como uma formação da consciência que pressupõe a apropriação de tradições culturais, filtrada pela reflexão e pela historiografia. Ele surge entre o público erudito e espalha-se pelos canais da moderna comunicação de massas. Tanto a mediação literária como a propagação ela mídia conferem ao nacionalismo características artificiais, tornando-o presa fácil do abuso e da manipulação através de elites políticas (HABERMAS, 1997, p. 281-282).
}

Diante do afirmado por Habermas, o nacionalismo se difunde, em princípio, partindo de grandes pensadores de uma sociedade, ou seja, até mesmo dentro das universidades, com pesquisas e teorias de cunho eugênico, por exemplo, para ser propagado de forma mais simplista para o restante da nação. Esse pensamento nacionalista, portanto, precisaria da fundamentação de grandes cátedras, de suas ratificações para então se justificar.

A seguir, ver-se-á quais as consequências do ressurgimento de movimentos de orientação nacionalista, no mundo e o impacto desse fenômeno na política recente no Brasil.

\section{A origem do ressurgimento de movimentos nacionalistas no mundo}

Observa-se há alguns anos o ressurgimento de uma extrema direita na política do continente Europeu em que, inicialmente, balizados na propaganda sobre os ataques terroristas do "Estado islâmico", iniciaram mudanças legais contra a entrada de imigrantes, fechamento físico de fronteiras, o não aceite do outro seja por sua religião, nacionalidade, cor, etnia. Ou seja, é algo cada vez mais pungente e preocupante a elevação de uma cultura do ódio ao outro, que representa um "inimigo". São vozes que coadunam em um raciocínio xenofóbico, cuja obsessão tem impactado, de forma geral, na política interna e externa.

Importa averiguar, todavia, qual a origem remota que desencadeou o ressurgimento de movimentos nacionalistas. Pois, a afirmação de que seria somente contra a entrada de imigrantes nos países desenvolvidos ou devido aos ataques terroristas sofridos parece uma resposta simplista para um tema de variada complexidade.

Após a Segunda Guerra Mundial, os Estados estavam fragmentados, e tentou-se a união e pacificação através de tratados, principalmente de viés econômico, como a União Europeia. 
Não se pode olvidar, contudo, que havia uma cisão dentro de vários países, como reflexo da Guerra Fria, isto é, com partidos que seguiam preceitos marxistas e partidos de partidos de economia liberal capitalista. Exemplo visível disso foi a Alemanha com seu território dividido.

Essa união de países em blocos econômicos para se protegerem e se fortificarem monetária e militarmente não levou em conta as mazelas sociais e políticas deixadas no restante do mundo, principalmente nos países em desenvolvimento.

Para conter os impulsos de participação popular das camadas sociais mais baixas cada vez mais crescentes - o Estado, em prol da expansão do capitalismo, exerce um controle ainda maior e repressivo em face de manifestações democráticas. O Estado atua como garantidor ao crescimento do capitalismo, regulando preços, diminuindo direitos sociais, relativizando normas em prol do capital.

Nisso posto, ao capital cabe, muitas vezes, apoiar discursos radicais para conter a população que reivindica direitos básicos, tolhendo, assim qualquer possibilidade de crescimento da democracia:

\begin{abstract}
Os mitos racistas e os antissemitismo estão desgastados, mas a "demonização" do socialismo continua a funcionar com excepcional eficácia. Políticos que nunca leram Hitler nem Mussolini falam do socialismo como uma força essencialmente antinacional, que deve ser implacavelmente combatida e aniquilada em nome da grandeza da nação, servindo-se quase que textualmente de expressões caras aos dois ditadores (KONDER, 2009, p. 178).
\end{abstract}

Vê-se que o socialismo, na versão dos políticos atuais de direita, se contrapõe ao nacionalismo, que seria o estandarte defendido para reerguerem suas economias, seja na Europa, Estados Unidos da América ou aqui no Brasil, o discurso tem o mesmo viés.

\title{
Conceito de fascismo e sua correlação com o nacionalismo
}

O fascismo ${ }^{3}$ nasce após a Primeira Guerra Mundial tendo como berço a Itália e semelhante atuação se deu na Alemanha, simultaneamente, com a nomenclatura de nazismo, tendo como ponto de intersecção entre ambos o uso de termos como socialismo e nacionalismo em suas "filosofias", ou "doutrinas".

\footnotetext{
${ }^{3}$ Fascismo advém de fascio em italiano que significa feixe, simbolizando união. Tendo em vista que a Itália havia passado por uma unificação no final do século XIX e acabou por ser derrotada na Primeira Guerra Mundial, o fascismo significaria essa união de todas as regioni com um grande evocação ao nacionalismo.
} 
Pode-se assim denominar doutrina, pois, tanto o fascismo quanto o nazismo traziam em seu modus operandi "verdades incontestáveis", dogmas, tal qual uma religião. Portanto, quem o seguisse não poderia contestar as falas apresentadas pelo líder e seus seguidores. Ademais, conseguia se estender a várias camadas da sociedade, pois "a demagogia fascista assume frequentemente formas 'populistas', lisonjeando o 'povo', prestando-lhe todas as homenagens e contrapondo-o à 'massa' (que representa apenas o peso morto da 'quantidade'" (KONDER, 2009, p. 40).

Alinhado a este entendimento, constata-se que o nacionalismo exaltado pelo fascismo, ou seja, a nação como mito, fora algo que agradou a todas as classes sociais:

\begin{abstract}
O nacional-socialismo veio, assim, a aproximar-se, tanto quanto possível, do sonho do político, de prometer tudo a todos. E esta foi realmente a estratégia adotada por Mussolini e Hitler até consolidarem o poder. A estratégia determinava a Filosofia, que devia ser uma forma exaltada de idealismo, em contraste com o materialismo marxista; [...] Uma vez que sobre fundamentos racionais essa política era totalmente irrealista, deveria ela elevar a intuição e a vontade acima da inteligência (SABINE, 1964, p. 849).
\end{abstract}

Nazismo seria, portanto, uma derivação ainda mais violenta do fascismo, onde, por meio dos ideais nacionalistas, construiu-se a ideia da união necessária para Itália e Alemanha, principalmente, emergirem economicamente após a derrota na Primeira Guerra Mundial.

Apesar da afirmação do fascismo ter conseguido adeptos de todas as classes, originariamente e em sua atualidade seu núcleo se firma na classe média. Em geral, uma classe média frustrada "[...] uma classe que sofre os efeitos de uma crise econômica ou abriga sentimentos de humilhação política, assustada pela pressão de grupos sociais subalternos" (BOITO, 2020, p. 114). Trata-se, portanto, de um movimento apoiado, principalmente, pela faixa econômica intermediária da sociedade.

Um outro elemento que configura o nacionalismo/fascismo é a eliminação de indivíduos contrários aos ideais do poder ou por apenas ser de determinada origem étnica, cultural, Foucault descreve como "biopolítica da espécie humana", e que seria uma regulação da população humana de acordo com o interesse político local, conforme explica Guilherme Castelo Branco ao analisar a teoria:

Tal modalidade para uso do poder para exemplificar, teve uma versão de extrema violência, nos tempos do Terror de Estado, na Argentina e Chile. Foi um tempo de eliminação de pessoas sob uma justificativa política de salvaguardar as nações latino-americanas (como outros) das ameaças do comunismo. Tal perseguição 
política não deixava de ter componentes biológicos, pois o militante político caçados e eliminável é percebido como portador de características genéticas e traços biológicos perigosos para o restante da sociedade (BRANCO, 2015, p. 70).

Os indivíduos que poderiam estar contrários aos interesses nacionais, ou que seriam inferiores por não pertencerem à "raça ariana", deveriam, portanto, ser eliminados como se deu no fascismo alemão, em que intersectou o pensamento nacionalista de uma só raça, povo, nação unificados trazendo a denominação de "as gentes":

As gentes eram chamadas de "raça", mas se identificavam também com a nação, que, como unidade cultural, se definia pelas características aprendidas, ou adquiridas, mas que não podiam ser herdadas. Significava também "povo" no sentido coletivo, mas se referiam regularmente a ele como se constituísse uma essência mística, do qual a pessoa era mera depositária (SABINE, 1964, p. 863).

$\mathrm{Na}$ ótica do psicanalista Wilhem Reich, o nacionalismo correlacionado ao fascismo, para ser fixado na mentalidade humana, abordou estruturas emocionais, cognitivas para ser tido como o certo a ser realizado, pois trabalhava com elementos ligados especialmente à honra, moralidade e controle:

É conhecida a escala de valores: honra pessoal, honra da família, honra da raça, honra nacional. Ela está organizada de acordo com as várias camadas da estrutura individual. Mas esquece-se de incluir a base socioeconômica: capitalismo ou sociedade patriarcal; a instituição do matrimônio compulsivo; repressão sexual; luta pessoal contra a própria sexualidade; compensação por meio do sentimento de honra pessoal etc. O auge desta escala é constituído pela ideologia da "honra nacional", que é o cerne irracional do nacionalismo (REICH, 1988, p. 62).

E ainda, para o mencionado psicanalista, a origem do sentimento nacionalista, ou o mito da nação, se dá na figura materna:

O sentimento nacionalista é, portanto, o prolongamento direto da ligação familiar e, tal como esta, tem a sua origem na ligação fixa à figura da mãe. [...] É nesta perpetuação socialmente motivada que a ligação à mãe constitui a base do sentimento nacionalista do homem adulto, transformando-se, assim, numa força social reacionária (REICH, 1988, p. 63).

\footnotetext{
${ }^{4}$ As gentes, volk em alemão e seu ideal de pureza e superioridade à demais nações é um conceito norteado por misticismo, pois Hitler seguiu a denominada teoria das raças de Alfred Rosenberg que o fez crer que "a raça ariana" teria surgido na Mesopotâmia (onde também se encontraram povos antigos que utilizavam a suástica como símbolo), originando as antigas civilizações como Pérsia, Grécia, Egito, Índia e Roma afirmando até mesmo que Jesus era ariano (SABINE, 1964, p. 868).
} 
Essas imagens são invocadas nos dizeres fascistas ao mencionarem que o amor à pátria e aceite cego de qualquer ordem determinada do "mito" deverá ser seguida.

Em relação à palavra mito, essa ideia se origina anteriormente à filosofia, primeiro se tem as mitologias que trabalham com vários deuses, funcionando por intensidade e não por argumento, ou seja, por apelo emocional e irracional. Crer no mito é crer, portanto, no herói, naquele que representa a esperança de salvação, de proteção. Logo, essa figura paternal, mítica, que é o escolhido, predestinado a conduzir a nação e suas ações não serão contestadas pois se trata de uma divindade.

\begin{abstract}
A relação entre o líder e as gentes seria essencialmente mística, ou irracional. Seria o que Max Weber chamou de "carismática", o que poderia ser expressado menos eruditamente se disséssemos que o líder seria uma espécie de mascote ou "sorte" do movimento. Ele seria um prolongamento das gentes, ligado ao povo pelo laço místico do sangue, derivando poder de suas raízes da raça orientando-a por uma instituição infalível que lembrava o instinto animal, e atraindo-as mediante uma afinidade que nada teria a ver com capacidade de convencer intelectualmente. Era o gênio ou herói, concebido como homem de pura raça (SABINE, 1964, p. 865).
\end{abstract}

Ademais, não somente o líder é tido como figura mítica na ideologia fascistas, mas, sobretudo, a nação é esse mito, criado inicialmente por Mussolini percebendo que deveria haver um princípio sagrado acima de qualquer discussão, ou seja, o amor à pátria: “Criamos o nosso mito. O mito é uma fé, é uma paixão. Não é preciso que seja realidade. [...] O nosso mito é a nação, o nosso mito é a grandeza da nação!" (apud, KONDER, 2009, p. 36).

Nota-se que há um grande apelo emocional à união desde o nome utilizado, fascio (feixe), até à invocação de palavras e aspectos emocionais humanos para fazer crer que os indivíduos estavam unidos a um movimento em favor de algo "sagrado", ou seja, a pátria que advém de uma origem sanguínea - liderados por um escolhido, um herói, um mito.

\title{
O fascismo travestido de nacionalismo no Brasil contemporâneo
}

Para demonstrar como o fascismo se instalou novamente no Brasil, revestido das características do nacionalismo, traçar alguns elementos que consubstanciam o fascismo e sua correlação com o discurso político atual.

Alguns elementos que evoca-se sobre o conceito de fascismo - como a biopolítica do poder trazida por Foucault - ressurgem nas falas do presidente atual e seus apoiadores ao 
negarem a letalidade de um vírus que assola o mundo, deixando milhares de vítimas, e ainda, nos dizeres de combate ao comunismo instalado no país. Tal discurso se reverbera no legislativo, evidenciado em projetos de Lei como o de número 5.358 de 2016, de autoria do filho do presidente da república, deputado Eduardo Bolsonaro (PSC-SP), que altera a redação da Lei no 7.716, de 5 de janeiro de 1989 (crimes raciais) e da Lei ํo 13.260 (crimes de terrorismo), de 16 de março de 2016, para criminalizar a apologia ao comunismo.

Outro aspecto persistente do fascismo em seu retorno ao cenário político nacional é o massivo apoio da classe média. Em seu afã de retomada do poder, elegeu para cargos tanto no legislativo quanto no executivo, pessoas despreparadas intelectual e emocionalmente que externaram o sentimento de revolta acercada de "seus privilégios" que foram estendidos aos mais pobres, como acesso às universidades, ao lazer, à cultura e classes antes tidas à margem da sociedade (indígenas, quilombolas, pobres da periferia), começaram a ter visibilidade, a ser enxergados através das redes sociais, das mídias, não como algo distante e distinto, mas como seres humanos, brasileiros.

Ademais, a fala do atual presidente é neoliberal, corroborada pelo Ministro da Economia, Paulo Guedes, e isso acaba por também conquistar a classe média, que, com a escusa de um combate à corrupção, bem como, o escopo neoliberal econômico que se apresentou o governo Bolsonaro, imaginaram que poderiam reascender:

\begin{abstract}
Quando economistas neoliberais falam sobre dar credibilidade aos investidores, é importante considerar que boa parte da classe média se sente, devida ou indevidamente, como pertencente a este grupo. [...] se Moro e a Lava Jato foram imprescindíveis no sentido de organizar o antipetismo da classe média e normalizar os métodos de exceção também defendidos por Bolsonaro, foi o capital financeiro que precificou o retorno que obteria com cada candidatura e considerou que a escolha mais racional seria auferir lucros sob a ameaça fascista (CAVALCANTE, 2020, p. 129).
\end{abstract}

Recordando o último processo eleitoral para presidente da república, houve uma nítida manipulação do candidato eleito na exaltação dos valores nacionais em sua campanha: o Hino, a Bandeira Nacional e suas cores e a elevação do amor à pátria. Jair Bolsonaro tomou posse desses símbolos nacionais para opor-se aos usados pelo partido adversário. ${ }^{5}$

\footnotetext{
${ }^{5}$ Não somente esses símbolos patrióticos foram usados, bem como os termos "família tradicional”, e ainda do uso de "valores cristãos" foram altamente manipulados, e, em contrapartida, sua campanha eleitoral fora pautada somente em combater as ideias de único partido, o Partido dos Trabalhadores (PT), que, segundo o
} 
Vê-se que, ao analisar o que descreveu Wilhem Reich acerca da ideologia nacionalista do regime nazista alemão, não foi distanciado do que se viu nas eleições de 2018 e se reitera na postura do atual governo federal.

O sociólogo italiano Domenico de Masi afirma que o presidente eleito é um político de inspiração fascista, pois a eliminação física de adversários era exatamente uma das características do regime de Mussolini, comparando-os:

Ele tem inspiração fascista no que diz respeito à relação do Estado com a economia, entre o poder civil e militar, política e religião. E com base num conceito de autoritarismo, acha que pode resolver problemas complexos com receitas fáceis (FERRAZ, 2018, p. s/n).

Mas, com um Congresso Nacional, em sua maioria, se coadunando com os ideais apregoados nas eleições, não seria vivenciado o mesmo ocorrido há décadas na Segunda Guerra Mundial, em que uma nação votou e aprovou, até mesmo fingiu não saber do holocausto?

Mas seria possível ainda o combate ao fascismo no Brasil, dissimulado de exaltação à pátria, travestido de "verde amarelo"?

Diante de todo o narrado vê-se o atentado que se aproxima ao Estado Democrático de Direito instituído pela assembleia constituinte em 1988, que originou a Constituição Federal atual, tendo como um de seus pilares a garantia da dignidade da pessoa humana e o pluralismo político.

Logo, o amor à pátria conclamado pelo governo eleito em 2018 é, em verdade, uma forma de manipulação estatal em prol do capitalismo, como se traduz hoje o fascismo. Os ditadores atuais servem ao capital, servem às empresas, grandes holdings que manipulam os mercados mundiais, assim, e, para isso, devem-se tolher os direitos humanos, distorcê-los em discursos como benesses demasiadas que favorecem somente a bandidos.

\section{Uma via de solução}

Em artigo publicado na Revista Cult, Ivana Bentes, pesquisadora em comunicação da Universidade Federal do Rio de Janeiro dispõe sobre o drama político e a ameaça à

presidente eleito, seria o mal que causou o decréscimo econômico no país e com ele, todas as causas que a esquerda exaltava deveriam ser juntamente combatidas: a liberdade sexual, a causa gay, feminismo etc. 
democracia e liberdade de expressão que foi vivenciado nas eleições, de 2018, e que assolam o país até os dias atuais:

O fascismo como desejo de poder acendendo todos os ressentimentos de grupos, de classe, as frustações pessoais, o desejo de morte dos que se sentem desorientados e humilhados e aceitam a promessa de assujeitar os outros. Não se reprima! Não se reprima! Conclama Bolsonaro para seus eleitores. Bolsonaro é o anti-herói que libera os nossos mais baixos e piores instintos. Exatamente como o fenômeno das fakenews, em que as pessoas querem acreditar por mais absurdas e inverossímeis que elas sejam. Essa eleição também desconfigura o campo da comunicação corporativa. Bolsonaro usou transmissões ao vivo no Facebook, um canal no Youtube e o impulsionamento de memes e fakenews em redes gigantescas e descentralizadas criadas no WhatsApp. Avalanches de fakenews, memes, teorias estapafúrdias, crenças, teorias conspiratórias, produção de medo, histeria, mas também contranarrativas, resistências e esperanças serão despejadas em uma corrente sanguínea que já começou a produzir anticorpos. As eleições de 2018 serão decididas por contágio e onda (BENTES, 2018, p. s/n).

Importante frisar que, no uso da linguagem, em principal pelos meios das redes sociais, o discurso usado pelo governo atual é de sempre culpar o partido anterior, a gestão anterior como responsável por todas as mazelas sociais vivenciadas, gerando, como visto na análise do fascismo, a eleição do inimigo, como forma de indução através do discurso.

Michel Foucault em sua obra "A ordem do discurso" debateu sobre o perigo existente na proliferação do discurso e qual seu real intuito, a conquista do poder:

\begin{abstract}
Por mais que o discurso seja aparentemente bem pouca coisa, as interdições que o atingem revelam logo, rapidamente, sua ligação com o desejo e com o poder. Nisto não há nada de espantoso, visto que o discurso - como a psicanálise nos mostrou não é simplesmente aquilo que manifesta (ou oculta) o desejo; é, também, aquilo que é objeto do desejo; e visto que - isto a história não cessa de nos ensinar - o discurso não é simplesmente aquilo que traduz as lutas ou sistemas de dominação, mas aquilo porque, pelo que se luta, o poder do qual queremos apoderar (FOUCAULT, 2014, p. 10).
\end{abstract}

Em outra análise se tem Habermas defendendo que o discurso seria uma forma da vontade racional, sendo que, a legitimidade do Direito está contida num arranjo comunicativo, que, através dos debates e dos argumentos apresentados, será avaliado se uma norma merece ser institucionalizada juridicamente.

Em sua teoria da razão discursiva traz o apontamento sobre a democracia que Habermas faz em seu livro Sobre a Constituição da Europa: 
[...] distinguirei três elementos que, de um modo ou de outro têm de ser incorporados em toda comunidade democrática: a comunitarização de pessoas que, em um espaço determinado, unem-se para formar uma associação de cidadãos e iguais, concedendo reciprocamente direitos que garantem a todos igual autonomia privada e pública; a distribuição de competências no espaço de uma organização que assegura, com meios administrativos, a capacidade de ação coletiva dos cidadãos e associados, e; o medium de integração de uma solidariedade civil estatal ou supraestatal necessária para uma formação política comum da vontade e, para a legitimação do exercício da dominação (HABERMAS, 2012, p. 58-59).

Nessa linha, Norberto Bobbio disserta acerca do combate ao fascismo nos dias atuais, apregoando que somente seria combatido através da renovação da democracia:

[...] se o fascismo é o fruto do enxerto das novas formas da exploração capitalista e monopólica no terreno tradicional do domínio e da opressão feudal, a revolução antifascista coincide com a transformação democrática das estruturas que geraram o fascismo e que tendem a reproduzi-lo constantemente (BOBBIO, 1998, p.36).

Logo, a mudança no exercício da democracia acenderia desse debate - contudo, deverá ser embasado em racionalidade, cientificismo e verdade - sendo que, a esfera pública teria que ouvir os problemas da população, "percebê-los, identificá-los, devendo, além disso, lematizá-los, problematizá-los e dramatizá-los de modo convincente e eficaz, a ponto de serem assumidos e elaborados pelo complexo parlamentar" (HABERMAS, 1997, p. 91). Assim, fortalecendo a democracia, o fascismo se torna cada vez mais difícil de ser reinstalado.

\section{Considerações finais}

Em sintonia com o discorrido pelos autores mencionados nesta breve exposição, vêse que a onda de nacionalismo que se instalou no país elegeu um inimigo, colocando o presidente em exercício como único capaz de combatê-lo, combater seus ideais de esquerda e tudo o que ela representa.

Bradando discursos de ódio racial, promulgando a misoginia, e, ao mesmo tempo, pregando ser um defensor de valores morais e conservadores, ser o patrono da família tradicional brasileira, o presidente atual respondeu ao anseio de grupos econômicos liberais, que detém interesse em minimizar a atuação legal econômica do Estado, deixando que "o capital siga seu próprio curso".

Percebe-se que o governo avança cada vez mais no intuito de tolher direitos antes garantidos, como a "contrarreforma" trabalhista e de igual gênero previdenciária, atacando 
direitos sociais, principalmente dos mais pobres, fazendo de reféns dos bancos nas previdências privadas todo seu eleitorado praticamente da classe média brasileira.

E, a olhos vistos, o denominado projeto de lei "excludente de ilicitude" é claramente inconstitucional, pois ao não punir excessos, violência e mortes causadas por policiais em operações o Estado legitimaria os crimes cometidos por abuso de autoridade, o despreparo desses. Em suma, tal projeto de lei fere a democracia, pois a atuação de policiais, forças armadas pode coibir as manifestações populares, concede-se uma "licença para matar" a esses profissionais que servem o governo.

Portanto, diante de um cenário cada vez mais restritivo de direitos que se impõe por ameaças já vislumbradas via instrumentos de comunicação em massa, e nos projetos de lei que tramitam no Congresso, o governo que se instalou no Brasil, a partir de 10 de janeiro de 2019, compartilha elementos temerários à democracia no país, já tão rara e ameaçada.

Onde não há democracia, há autoritarismo, e os dois não podem coexistir para o bem da nação.

\section{Referências}

ARENDET, H. A condição humana. 10a ed. Tradução de Roberto Raposo. Rio de Janeiro: Forense Universitária, 2007.

ARISTÓTELES. Política. São Paulo: Martin Claret, 2004.

AZAMBUJA, D. Teoria geral do estado. 36 ed. São Paulo: Globo, 1999.

BAALBAKI, S. O Estado, o povo e a soberania. Revista Jus Navigandi, Teresina, ano 10, n. 759, 2 ago. 2005. Disponível em: https://jus.com.br/artigos/7045. Acesso em: 15 dez. 2018.

BENTES, I. As milícias digitais de Bolsonaro e o colapso da democracia. Revista CULT, Rio de Janeiro, 24 de out. de 2018. Disponível em: https://revistacult.uol.com.br / home/naomatem-a-democracia/. Acesso em: 15 dez. 2018.

BOBBIO, N. Dicionário de política. vol.1, 11a ed. Brasília: Editora Universidade de Brasília, 1998.

BOITO JR, A. Por que caracterizar o bolsonarismo como neofascismo. Crítica Marxista, n. 50, ano 2020. p. 111-119. Disponível em: https://www.ifch.unicamp.br/ critica marxista/arquivos biblioteca/dossie2020 $05 \quad 2614 \quad 12$ 19.pdf. Acesso em: 28/ 05/2020.

CANOTILHO, J. J. G. Direito constitucional. 6a ed. rev. Coimbra: Livraria Almedina, 1993. 
CAVALCANTE, S. Classe média e ameaça neofascista no Brasil de Bolsonaro. Crítica Marxista, n. 50, ano 2020. p. 121-130. Disponível em: https://www.ifch.unicamp.br/ criticamarxista/arquivos biblioteca/dossie2020 $05 \quad 26 \quad 14 \quad 12$ 19.pdf. Acesso em: 28/05/2020.

CHAUI, M. Convite à Filosofia. São Paulo: Editora Ática, 1995, 3a edição.

COMPARATO, F. K. A Afirmação Histórica dos Direitos Humanos. São Paulo: SARAIVA, 2015.

CORDEIRO, T. Como a suástica virou a marca do nazismo? Revista Superinteressante. 10 de outubro de 2018. Disponível em: https://super.abril.com.br/historia/como-a-suastica-viroua-marca-do-nazismo/. Acesso em: 10 de dez. de 2018.

DAL RI JÚNIOR. A. A Nação Contra o Estado. A Ciência do Direito Internacional no "Risorgimento" Italiano Anuário Brasileiro de Direito Internacional. Coordenador: Leonardo Nemer Caldeira Brant - v.1, n.10. Belo Horizonte: CEDIN, 2011.

DURANT, W. A História da Civilização: Nossa Herança Clássica, São Paulo: Companhia nacional, 1943.

DWORKIN, R. Levando os direitos a sério. Trad. Nelson Boeira. 3. ed. Martins Fontes: São Paulo, 2010.

FERRAZ, L. O que é o fascismo? Perguntamos aos pensadores da Itália, berço do movimento. Disponível em: https://www.bbc.com/portuguese/internacional-5750065. Acesso em: 22/12/2018.

GUIMARÃES, S. P. Nação, nacionalismo, Estado. Revista Estudos avançados. vol. 22, no 62. São Paulo: USP. jan./abr. 2008.

HABERMAS, J. Direito e democracia: entre facticidade e validade, volume II. Tradução: Flávio Beno siebenichler - Rio de Janeiro: Tempo Brasileiro, 1997.

. Entre Naturalismo e Religião. Estudos filosóficos. Tradução: Flávio Siebeneichler. Rio de Janeiro: Tempo Brasileiro, 2007.

Sobre a constituição da Europa: um ensaio. Tradução Denilson Luis Werle, Luiz Repa e Rurion Melo. São Paulo. E. Unesp, 2012.

IHERING, R. von. A luta pelo direito. São Paulo: Revista dos Tribunais. 2004.

KELSEN, H. Teoria Pura do Direito. 7ạ ed. São Paulo: Martins Fontes, 2006.

KONDER, L. Introdução ao fascismo. 2ª ed. São Paulo: Editora Expressão Popular, 2009.

REICH, W. Psicologia das massas do fascismo. 2a ed. brasileira, São Paulo: Martins Fontes, 1988. 
RIBEIRO, P. H. O renascimento do nacionalismo na Europa. Gazeta do Povo, Curitiba. 08 de julho de 2018. Editorial, artigos. Disponível em: https://www.gazetado povo.com.br/opiniao/artigos/o-renascimento-do-nacionalismo-na-europa-

5l8swpahsieekoyekwye451mh/. Acesso em: 10/04/2020.

SABINE, G. H. Histórias das teorias políticas. Rio de Janeiro: Editora Fundo de Cultura, 1964.

SAVIGNY, F. Carl von. Traité de droit romain. Tome 1. Paris: Firmin Didot Frères, 1840.

SOBRINHO, A. J. B. L. Nacionalismo. Disponível em: http://www .fgv.br/cpdoc/acervo/ dicionarios/verbete-tematico/nacionalismo. Acesso em: 17/03/2019.

SOUSA, J. P. G. de 1912-Direito natural, direito positivo e estado de direito. São Paulo: Editora Revista dos Tribunais, 1977.

TAVARES, A. R. Curso de Direito Constitucional. 10a ed. rev. e atual. São Paulo: Saraiva, 2012. 